\title{
THE DILEMMA OF KNOWLEDGE MANAGEMENT IN AN ORGANIZATION
}

\author{
Agnieszka Bieńkowska ${ }^{1}$, Beata Ignacek-Kuźnicka²
}

\begin{abstract}
In scientific discourse, opinions exist about the passing of knowledge management. These voices are incompatible with an argument that, in the era of knowledge-based economies, organizations need to be moving towards this concept of knowledge management. Such divergence requires examination. Hence, this paper presents the findings of a thorough literature review aiming to examine how widespread knowledge management solutions have been adopted in organizations as well as to identify the traits that define a knowledge worker. Also, the paper identifies the relationship between knowledge management and human resource management in the context of supporting knowledge workers. A critical analysis of literature together with theoretical conclusions are the main research methods used. The article is the basis for further empirical verification of the problem. The results indicate that the implementation of knowledge management can be a trend without formal acknowledgment. Thus, without obvious intention, the organization implements a management method that fulfills the premises of knowledge management. This paper presents an interpretation of knowledge management that invalidates the passing of this knowledge field.
\end{abstract}

JEL Classification Numbers: M50, M10; DOI: http://dx.doi.org/10.12955/cbup.v5.924

Keywords: knowledge management (KM), knowledge workers (KW), human resource management (HRM)

\section{Introduction}

Knowledge workers benefit organizations because they directly participate in the research, creation, practical use, and extension of strategic resources of that organization, or in other words, knowledge. The extraordinary role played by knowledge workers (referred to as $\mathrm{KW}$ in this paper) implies a need for their special treatment so they can develop and use their competencies unhindered. It seems a natural progression to support the development of solutions that benefit KW by a system of knowledge management (referred to as KM in this paper). However, there are several dilemmas regarding this area. First, it is unknown how widespread KM solutions have been adopted by organizations since, although KW are identifiable, it is not possible to exclude situations in which KM solutions remain unimplemented. Second, the form of the specific KM solution dedicated to KW remains a dilemma. Third, one needs to fully study the relationship between KM and human resource management (HRM), especially in the context of support for the KW, who seem to lead the KM of the organization. In literature, theses have evaluated the assumptions of both concepts. It is clear that implementing the human resource function for KW needs to be specific (from recruitment to motivation).

The three problems mentioned above can be specified by the following research questions: Is KM common in an organization? Can the implementation of KM in an organization occur unconsciously? Are statements concerning the passing of issues related to KM definite? Is the traditional concept of a 'brain-worker' the same as the modern concept of the knowledge worker? What are the relationships between KM and other management concepts, notably those of HRM? How should an organization create KM and HRM solutions to support KW?

This study aims to answer these research questions by way of a thorough literature review to detail the categories relating to KM. Also, the considerations include whether the traditional concept of brainworker is the same as the modern concept of KW.

\section{Conscious and Unconscious Knowledge Management in an Organization}

The origins of issues relating to knowledge management date back to the nineteen-fifties. However, today, in scientific discussions, voices are proclaiming their imminent passing. This opinion is controversial, especially when one considers that in the era of a knowledge-based economy organizations are needing to move towards the concept of KM. Possibly a reason for these controversial statements about the passing of KM is that when an organization adopts this concept, the process may seem semi-intentional. Specifically, this can relate to a situation where management supports the premise but fails to implement KM directly. This case raises the question of what constitutes the distinguishing features in such an organization.

\footnotetext{
${ }^{1}$ Wroclaw University of Technology, ziro@pwr.edu.pl

${ }^{2}$ A solicitor, bignacek@gmail.com
} 
Regarding whether KM is a common phenomenon or not, one should first refer to Tabaszewska (2011, p. 64), who concluded that all organizations have managed knowledge in the past and will continue to manage such today. At the same time, Tabaszewska advocated diversity of professionalism regarding formal and, consequently, theoretical preparation and implementation. Tabaszewska used gradation to develop different categories of KM. Morawski (2011, p. 13) stated that the first category, 'focus on knowledge', can be defined as the continuous movement of knowledge within an organization. This claim is rational, since the focus on knowledge, according to Drucker (2011, p. 166), is the goal toward which the organization aims; it reorganizes the present to develop a better future. The continuous movement of an organization towards knowledge and reorganization (resulting from the need to seek knowledge), as discussed by Drucker, is maintained by perpetually stimulating the exchange of knowledge (Jashapara, 2014, p. 365). This case is implied among people within the organization as the constant transformation of explicit knowledge, combining innovation and ideas (Morawski, 2011, p. 15), that dynamically provide the organization with unique authority. A focus on knowledge is therefore somewhat intentional KM. Hence, regarding the original question of whether $\mathrm{KM}$ can be implemented unknowingly, the answer seems to be affirmative. This is concluded because the tendency for knowledge to circulate occurs, though purely from the rational management of the organization while there is a lack of awareness in the matter and lack of professionalism.

Stimulating knowledge exchange with its notorious transformation and constant updating to dynamically provide the organization with unique knowledge becomes routine with an advanced focus on its awareness in an organization. This outcome leads to the next category relating to the concept of KM, knowledge creation. The author of this category, Oleksyn (2014, pp. 559-560), claimed that organizations that use and also generate knowledge need to be defined as organizations created by knowledge. Oleksyn (2014, p. 126) also drew attention to another phenomenon: the absorption of knowledge management in the administration of professional development. In this phenomenon, an organization does not need to identify KM, as such tasks are implemented within the framework of professional development. Furthermore, Tabaszewska (2011) considered that KM had always existed and Drucker (2011, pp. 98-99, 119, 165-166, \& 221-222) reiterated that the management of a brainworker is a conscious projection of a habit to supersede the present. Hence, it would appear that KM does not require many commands or specific control, but only an entrenched habit to make it effective.

The phenomenon of absorbing KM by other modes of managing an organization is evidenced by the multitude of categories relating to it. Tabaszewska (2011) indicated that the phenomenon gives rise to various forms of knowledge management systems and the following is a translated quotation about such forms: Some emphasize the use of information technology, which often focuses on information management rather than knowledge. The following are translated statements of Tabaszewska (2011, p. 60): Others establish the dominant role of sharing knowledge or building a system of continuous education; only a few organizations can create a knowledge management system that integrates all activities. The passing of issues related to $\mathrm{KM}$ does not occur, although terminology changes that result from the evolution of KM indeed take place. Thus, there is, no justification for the pessimistic visions concerning this field.

\section{Identifying the Knowledge Workers in an Organization}

When KM advances to the concept of strategic management of an organization, the importance of KW shifts into the foreground and thus, interpreting this concept becomes paramount. From a narrow traditional perspective, Kowalski (2011, pp. 315-316) developed a closed catalog of traits of KW, which are formal education, taxonomically listed professions, active participation in acquiring knowledge, autonomy, and performing under pain of bearing the consequences. According to Wellin (2013, p. 123), KW are experts in their field (law, accounting, and architecture) who share their knowledge with clients. Drucker (2011, p. 132) provided other examples: doctors, teachers, and preachers, along with lawyers, in the class termed 'traditional professions'. Jashapara (2014, p. 300) gave a similar set of examples of $\mathrm{KW}$, but at the same time reduced these to a common denominator, the culture of individuality. This culture consists of an individual's autonomy with simultaneous collective cooperation, which provides the opportunity for fulfilling an individual's passions. More precisely, this culture of individuality needed to be incorporated into the knowledge worker's skills. The narrow definition presented above includes one additional major premise, namely, the professional ethos. This premise is found in Kowalski (2011) in the discussion about performance 
under pain of bearing consequences. Thus, in this respect, a professional is a brain-worker combined with the ethos of their profession. It should be noted that a professional in the narrow sense of the word, is not necessarily a brain-worker, not according to the literal interpretation.

The traditional understanding of KW was ultimately evaluated by Drucker (2011, pp. 132-133) who wrote: "Knowledge workers today is used productively by an organization" and "business and state administration." A skilled brain-worker in this structure holds highly specialized knowledge and tends to play an active and autonomous role in decisions while communicating with workers according to the logic of the situation rather than the formal structure of competence. At present, the professional ethos has been replaced by an individual system of values, prestige, and ethical codes. The popularity of the latter increased dramatically after the bankruptcy of the Lehman Brothers in 2008. In summary, based on the literature (Drucker 2011; Jashapara 2014; Kowalski, 2011; Wellin, 2013) the traditional understanding of the notion of KW is characterized by the following premises:

1. Erudition - which has formal education; expert in the given field;

2. Professionalism - taxonomically listed professions

3. Autonomous participation in knowledge processes - given examples are types of freelance;

4. Professional ethos - moral responsibility.

It is necessary to create a contemporary catalog of the knowledge worker's predispositions in a broad sense, taking into account the considerations mentioned above. Also, Drucker's position and the view of Bogdziewicz (Juchnowicz, 2009, p. 144) consider the future of professionalism and the current trait of knowledge workers, as generally and commonly having a greater presence in the attitude of future generations of employees experiencing the development of the knowledge-based economy. Based on this in-depth literature study, specific traits of the knowledge worker were defined according to constitutive and descriptive values (Table 1). These descriptive characteristics were taken from detailed descriptions of scientists that help develop, define, and complete the image of the established KW.

Table 1: Contemporary catalog of knowledge worker's predispositions based on literature

\section{CONSTITUTIVE TRAITS OF KNOWLEDGE WORKERS} PERFECT REPUTATION

(high position and responsibility as an entity who has impact on the success of the organization

- take responsibility for their competence and standards of work (Drucker, 2011, p. 99)

- work in conditions of uncertainty (Makowski, 2012, p. 395)

- tend to take risks and responsibility (Staniewski, 2012, p. 347)

- should know the needs, attitudes, limitations, and perception of others to enable them to use their own achievements (Drucker, 2011, p. 94)

- responsible for creating innovations (Bieńkowska, 2009, pp. 245254)

- hold such a unique level of knowledge, that they decide about the success of the organization (Kowalski, 2011, p. 309)

- vibrant in shaping the added value of the organization (Kowalski 2011, pp. 315-316)

- active contributor to the success of the organization (Bailey, Bogdanowicz, 2001 cited Kowalski, 2011, p. 317)

- ready to take responsibility for the achieved results (Bieńkowska, 2009, pp. 245-254)

- hold vast competence (Drucker, 2011,p. 118)

- work on liability positions (Drucker, 2011, p. 24)

- make decisions (Drucker, 2011, p. 221)

- concentrated on the input for an entrenched habit (Drucker, 2011 p. 99)

- people who have graduated universities in both soft skills and technology, and as a result, can already judge the usefulness of the project in the initial phase of the project" (Drucker, 2011 cited Kowalski, 2011, p. 310)

PERSPICACITY (innovative)

- productive (Kowalski, 2011, p. 315-316)
- innovative (Staniewski, 2012, p. 347; Kowalski, 2011, pp. 315316)

- charismatic interpreter of the economic reality (Perchuda, 2007 cited Kowalski, 2011, p. 312)

- have unconventional ideas (Makowski 2012, p. 405)

- independent (Makowski, 2012, p. 408)

- critical (Makowski, 2012, p. 408)

- reflective (Makowski, 2012, p. 407)

- hold the skill of abstract thinking (Latusek-Jurczak 2012, p. 376)

- the reflective and analytic way of understanding reality (Jashapara, 2014, p. 303)

- have intuition (Jashapara, 2014, p. 303)

- have premonitions (Jashapara, 2014, p. 303)

- specialists who can find a link between one's own narrow field and the whole universe of knowledge, i.e. unmystified integrity (Drucker, 2011, p. 94) INTELLECTUAL erudite

- open (Staniewski, 2012, p. 348)

- open to knowledge (Morawski, 2009 cited Kowalski, 2011, pp.

311, 316-317)

- constantly learning (Kowalski, 2011, pp. 315-316)

- specialized intellectual (Davenport, 2007 cited in Kowalski, 2011, pp. 311, 316)

- devote most of their time to seeking, creating, using practically and spreading knowledge (Bieńkowska, 2009, pp. 245-254)

- innovative and creative (Bieńkowska, 2009, pp. 245-254)

- open-minded (Staniewski, 2012, p. 348)

- find it easy to transfer and use knowledge (Staniewski 2012, p. 347)

- creative (Staniewski, 2012, p. 347)

- know the values and beliefs of an individual (Jashapara, 2014, p. 303)

- brain-workers who create knowledge, ideas, and information (Drucker, 2011, p. 18) 
- have their own work instruments, interests, jargon (Drucker, 2011, p. 92)

- erudite (Drucker, 2011, p. 93 )

"PROFESSIONAL

a person with excellent professional skills"

- involved (Bieńkowska, 2009, pp. 780-789)

- involved (Staniewski, 2012, p. 348)

- their professionalism is above average (Drucker, 2011 cited Kowalski, 2011, p. 310)

- independent and responsible professionals who are aware of their own extraordinary competence (Morawski, 2009 cited Kowalski, 2011, pp. 311, 316-317)

- of unique knowledge, which is difficult to copy, invisible to outsiders (Staniewski, 2012, p. 343)

- passionate (Kuźmiński 2012, p. 18)

- an expert, passionate (Latusek-Jurczak, 2012, p. 376)

- professional (Makowski, 2012, p. 405)

- genuinely interested in their profession (Oleksyn, 2014, p. 440)

- develop their personal passions (Jashapara, 2014, p. 300)

- hold procedural knowledge "I know how" (Jashapara, 2014, p. 303)

- an active person holding quiet knowledge (Morawski, 2011, p. 15)

- professionals who work alone (Drucker, 2011, p. 21)

- hold knowledge which provides them with the freedom of

changing work (Drucker, 2011, p. 235)

- act in the sphere of highly specialized knowledge (Drucker, 2011, p. 98)

- experts with a high level of specialized knowledge (Drucker, 2011, p. 92)

\section{DESCRIPTIVE TRAITS OF KNOWLEDGE WORKERS}

\section{ETHICALITY}

- require that their work and position in the organization meet their mental needs and their personal value system (Drucker, 2011, p. 235)

- ethical (Morawski, 2009 cited Kowalski, 2011, p. 311, 316-317)

- equitable - follows ethical norms (Kowalski 2011, p. 320-321)

- trusted (Makowski, 2012, p. 411)

- caring (Jashapara, 2014, p. 303)
- trusted (Jashapara, 2014, p. 303)

- prepared for sacrifice (Jashapara, 2014, s. 303)

- compassionate (Jashapara, 2014, p. 303)

- demand and hard work from themselves (Drucker, 2011, p. 101)

apart from financial satisfaction, they need opportunities, achievements, self-fulfillment, and values (Drucker, 2011, p. 237)

\section{INDEPENDENCE}

- prefer to work freely (Davenport cited Kowalski, 2011, p. 311)

- independent (Morawski, 2009 cited Kowalski, 2011, pp. 311, 316317)

- mobile (Kowalski, 2011, pp. 315-316)

enjoy freedom in planning their work (Gurteend, 2006 cited Kowalski, 2011, p. 317)

- flexible in work (Bieńkowska, 2009, pp. 245-254)

- enjoy independence (Bieńkowska, 2009, pp. 245-254)

- free (Koźmiński, 2012, p. 18)

- cannot be subjected to strict, detailed supervision (Drucker, 2011, p. 18)

- require the minimum of orders and control (Drucker, 2011, p. 98)

- work with others voluntarily (Drucker, 2011, p. 98)

- work in spontaneously self-organizing teams (Drucker, 2011, p. 98-99)

- in the sphere of knowledge, they have not got subordinates and superiors, only older and younger colleagues (Drucker, 2011, p. 235)

\section{COOPERATIVITY}

- cooperative (Davenport, 2007 cited Kowalski, 2011, pp. 311, 316)

- open to interdisciplinary work (Bieńkowska, 2009, pp. 780)

- prepared to share knowledge (Bieńkowska, 2009, pp. 780-789)

- recognize themselves as specialists and also are perceived that way, however the take orders, as employees (Drucker, 2011, p. 235) - work together to achieve common aims (Drucker, 2011, p. 98)

- make their knowledge authority subject to the goals of the organization (Drucker, 2011, p. 235)

- constantly inform colleagues about the situation (Drucker, 2011, pp. 98-99)

- communicate within a team (Drucker, 2011, pp. 98-99)

- open to others (Kowalski, 2011, pp. 320-321)

Source: Authors

Knowledge Management and Human Resource Management

Knowledge management is a comprehensive approach that applies to every area of an organization. In this context, relating KM with other management concepts is unavoidable. The most frequently discussed relationships are between KM and total quality management (TQM; Zhao \& Bryar 2001; Ruţevičius, 2006), CRM (Stefanou, 2003; Porębska-Miąc, 2005; Liew, 2008), KM and enterprise resource planning (ERP; Chan et al., 2009; Metaxiotis, 2009), and KM and balanced scorecard (BSC; Wen \& Lin, 2002; Darvish et al., 2012). Contemporary KM is increasingly becoming integrated with other management concepts given that many areas are common to each. The issue of co-occurrence of KM with other management methods has been partially discussed, e.g., by Bieńkowska, WaleckaJankowska, and Zgrzywa-Ziemak (2013).

One concept that seems to coexist with KM naturally is HRM. This is supported by the following translated quotation: One can even speak about the tendency to use KM techniques to support staffing and retention efforts in an organization, as well as the acquisition and dissemination of knowledge hidden within the organization (Roberts-Witt, 2003 cited Staniewski, 2008, p. 358).

The interaction between KM and HRM is evident (see Armstrong, 2009, pp. 219 \& 225). However, it has not been thoroughly recognized in the literature, especially in the context of developing solutions dedicated to knowledge workers. Whelan and Carcary (2011) have rigorously analyzed the relationship between these methods and have emphasized that effective KM depends on successful management of those people of the organization who have key knowledge. On the one hand, management by competence should set the objectives for KM in areas relating to key competence, from both the perspective of the whole enterprise and that of its individual workers (who hold certain positions). On the other hand, KM should provide the necessary information for HRM, by using state metrics. Both methods should also provide motivation for workers. 
Contemporary features that define KW have a direct impact on the formation of specific solutions for KM and HRM, which are dedicated to these entities. Solutions for knowledge workers are required, and they include those specific approaches that integrate system-wide solutions and specific HRM guidelines. The results of a study conducted by researchers from the Warsaw School of Economics (Staniewski, 2008, p. 31-32) imply that when implementing system-based KM, Polish managers expect a beneficial movement of the organization around knowledge, as shown in Figure 1.

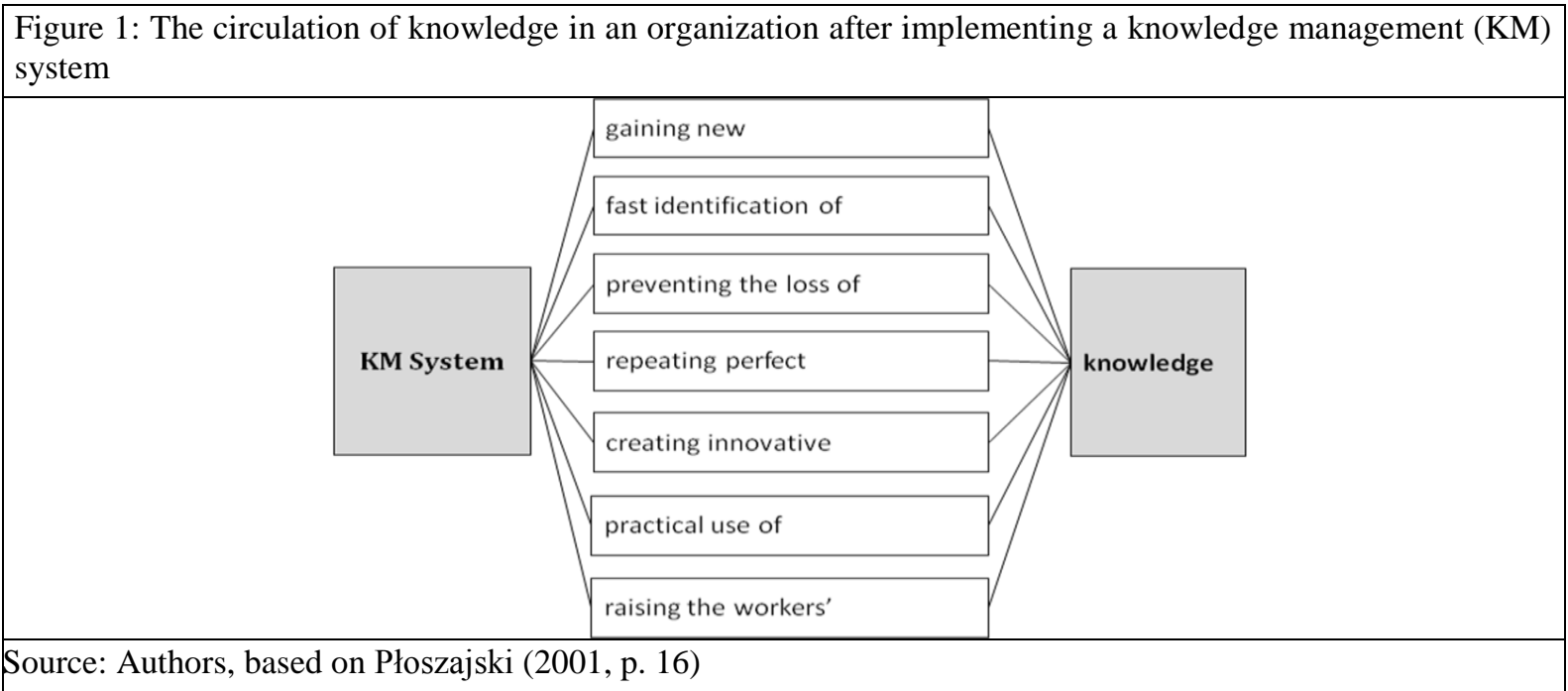

The benefits of implementing a KM system that the managers expect, are consolidated with their specific anticipations in the field of HRM, namely, as Fryczyńska (Fryczyńska, 2004, cited Staniewski, 2008, p. 31-32) lists in hierarchical order: "fuller satisfaction of the clients' needs, growth of work efficiency, growth of workers' motivation and satisfaction, gaining qualified workers".

Integration of a KM system with specific HRM guidelines leads to the rational use of working time, which avoids time wasted on the chaotic circulation of knowledge. In contrast, regulated exchange of knowledge would minimize the time needed for decisions, as in when responding to market needs, since such a system could appropriately structure and then effortlessly deliver information about customers and competition. This approach directly affects the development of the workers' competence. Ultimately, all such efforts result in a significant increase in the efficiency of the organization (Tomczak, 2007, p. 5).

\section{Conclusion}

The results of this study exclude the risks of absorption of KM in organizations. The scientific notions defining this issue are relevant in light of imminent economic transformations given the imperative progress of technology and information. Therefore, postponing this type of management is not recommended. However, the pace of knowledge evolution remains an open issue. One should expect the systematic expansion of $\mathrm{KM}$, as well as its rapid progression, and eventual revolutionary transformations into knowledge-based organizations. In the premises of KM, the importance of the knowledge worker has shifted to the foreground. Therefore, studying and interpreting this notion thoroughly in line with the ultimate purpose of this article, of initiating exploration leading towards ways of motivating $\mathrm{KW}$, is necessary.

\section{References}

Armstrong, M. (2009). Armstrong's Handbook of Human Resource Management Practice (1 th $^{\text {th }}$ ed.). London-Philadelphia: Kogan Page.

Bieńkowska, A. (2009). Praca oparta na wiedzy w polskich jednostkach badawczo rozwojowych. In E. Skrzypek Kreatywność i przedsiębiorczość w projakościowym myśleniu i działaniu. Lublin: Zakład Ekonomiki Jakości i Zarządzania Wiedzą, Wydział Ekonomiczny, Uniwersytet Marii Curie-Skłodowskiej, pp. 245-254.

Bieńkowska, A. (2009). Pracownicy wiedzy w jednostkach badawczo-rozwojowych w Polsce. Prace i Materiały Wydziału Zarządzania Uniwersytetu Gdańskiego. Vol. 2, No. 3, pp. 780-789.

Bieńkowska, A., Walecka-Jankowska, K. \& Zgrzywa-Ziemak, A. (2013). Zarzq̨dzanie wiedzq i inne metody - efekty wspótwystępowania. Przegląd Organizacji. Vol. 9. pp. 10-16. 
Bogdziewicz, P. (2009). Autodefinicje tożsamościowe pracowników wiedzy jako wyzwanie dla zarządzania zasobami ludzkimi w organizacjach. In Juchnowicz M. (ed.), Kulturowe uwarunkowania zarządzania kapitałem ludzkim. Cracow: Oficyna a Wolters Kluwer business.

Chan, E.W.L., Walker D.H.T., Mills, A. (2009). Using a KM framework to evaluate an ERP system implementation. Journal of Knowledge Management. Vol. 13, No. 2. pp. 93-109.

Darvish, H., Mohammadi, M. \& Afsharpour, P. (2012). Studying the Knowledge Management - Effect of Promoting the Four Balanced Scorecard Perspectives: A Case Study at SAIPA Automobile Manufacturing. Economic Insights - Trends and Challenges. Vol. LXIV, No. 1, pp. 9-23.

Drucker, P. F. (2011) Menedżer skuteczny Warsaw: Wyd. NT Biznes.

Fryczyńska, M. (2004). Zarządzanie wiedzą - przemijająca moda? Zarządzanie Zasobami Ludzkimi. No. 6. Retrieved from http://staniewski.vizja.pl/pdf/Vizja-Staniewski-Zarzadzanie-Zasobami-Ludzkimi-a-zarzadzanie-wiedza-wprzedsiebiorstwie.pdf

Intelektualista. (n.d.). In Wikipedia. Retrieved March 5 2017, from https://pl.wikipedia.org/wiki/Intelektualista Jashapara, A. (2014). Zarządzanie wiedza (2nd ed. Revised) (Sawicki J, Trans.). Warsaw: Polskie Wydawnictwo Ekonomiczne.

Kowalski, T. (2011). Pojęcia i cechy pracownika wiedzy. Studia lubelskie. Vol. 7.

Koźmiński, A.K. (2012). Wstęp, In D. Jemielniak \& A. K. Koźmiński (Eds.). Zarzadzanie wiedza (2nd ed.). Warsaw: Oficyna a Wolters Kluber business.

Latusek-Jurczak, D. (2012). Zadania liderów w stymulowaniu kreatywności i w zarządzaniu wiedzą. In D. Jemielniak \& A K. Koźmiński (Eds.). Zarządzanie wiedza (2nd ed.). Warsaw: Oficyna a Wolters Kluwer business.

Liew, C.B.A. (2008). Strategic integration of knowledge management and customer relationship management. Journal of Knowledge Management. Vol. 12, No. 4, pp. 131-146.

Makowski, D. (2012). Pracownicy intelektualni. Profesjonalizacja wiedzy. In D. Jemielniak \& A. K. Koźmiński (Eds.). Zarzadzanie wiedza (2nd ed.). Warsaw: Oficyna a Wolters Kluwer business.

Metaxiotis, K. (2009). Exploring the rationales for ERP and knowledge management integration in SMEs. Journal of Enterprise Information Management. Vol. 22, No. 1/2, pp. 51-62.

Morawski, M. (2011). Koncepcja zarządzania wiedzą w przedsiębiorstwie. In M. Morawski Mieczysław \& M. Prudzienica (Eds.). Zarzadzanie wiedza w kreowaniu innowacji zarządczych. Wroclaw: Wydawnictwo Uniwersytetu Ekonomicznego we Wrocławiu.

Oleksyn, T. (2014). Zarządzanie zasobami ludzkimi w organizacji (3rd Ed. Updated and Expanded). Warsaw: Oficyna a Wolters Kluwer business.

Płoszajski, J. (2001). Zarządzanie wiedza w Polsce. Bilans doświadczeń (Unpublished research statement). Warsaw, Katedra Teorii Zarządzania SGH 2001.

Porębska-Miąc, T. (2005). Wiedza i zarządzanie wiedzą w systemie CRM. In Porębska-Miąc, T., Sroka, H. (Eds), Systemy wspomagania organizacji Katowice: Wyd. AE.

Profesjonalista. (n.d.). In Stownik Języka Polskiego, Retrieved March 52017 from http://sjp.pl/profesjonalista.

Roberts-Witt, S.L. (2003). Reinventing HR. Knowledge Management. Retrieved July from <www.destignationKM.com>.

Ruţevičius, J. (2006). Integration of TQM and KM. Informacijos Mokslai. Vol. 37, pp. 30-38.

Staniewski, M. (2008). Zarządzanie zasobami ludzkimi a zarządzanie wiedzą w przedsiębiorstwie. Retrieved from <http://staniewski.vizja.pl/pdf/Vizja-Staniewski-Zarzadzanie-Zasobami-Ludzkimi-a-Zarzadzanie-wiedza-wprzedsiebiorstwie.pdf $>$.

Staniewski, M. (2012). Zarządzanie zasobami ludzkimi a zarząadzanie wiedzą. In D. Jemielniak \& A. K. Koźmiński (Eds.). Zarzadzanie wiedza (2nd ed.). Warsaw: Oficyna a Wolters Kluwer business.

Stefanou, C.J., Sarmaniotis, C. \& Stafyla A. (2003). CRM and customer-centric knowledge management: an empirical research. BPM Journal. Vol. 9, No. 5, pp. 617-634.

Tabaszewska, E. (2011). Implementacja systemów zarządzania wiedzą. In M. Morawski Mieczysław \& M. Prudzienica (Eds.). Zarzadzanie wiedza w kreowaniu innowacji zarzadczych. Wroclaw: Wydawnictwo Uniwersytetu Ekonomicznego we Wrocławiu.

Tomczak, P. (2007). Jak polskie firmy zarządzają wiedzą?. E-mentor. czasopismo elektroniczne SGH. Vol. 10. Retrieved from <http://staniewski.vizja.pl/pdf/Vizja-Staniewski-Zarzadzanie-Zasobami-Ludzkimi-a-zarzadzanie-wiedza-wprzedsiebiorstwie.pdf $>$.

Wellin, M. (2013) Zarządzanie kontraktem psychologicznym, zaangażowanie pracowników w zwiększanie wydajności firmy (K. Wackowska, Trans). Warsaw: Oficyna a Wolters Kluwer business.

Wen, Y., \& Lin, S. (2007). Utilizing the balanced scorecard for performance measurement of knowledge management. Journal of Accounting, Finance \& Management Strategy. Vol. 3, No. 2, pp. 39-58.

Whelan, E. \& Carcary, M. (2011). Integrating talent and knowledge management: where are the benefits? Journal of Knowledge Management. Vol. 15, No. 4, pp. 675-687.

Zhao, F. \& Bryar P. (2001). Integrating Knowledge Management and Total Quality: A Complementary Process. Proceeding of the $6^{\text {th }}$ International Conference on ISO 9000 and TQM, 17-19 April 2001. pp. 390-395. 